\title{
Assessment of the main factors impacting community members' attitudes towards tourism and protected areas in six southern African countries
}

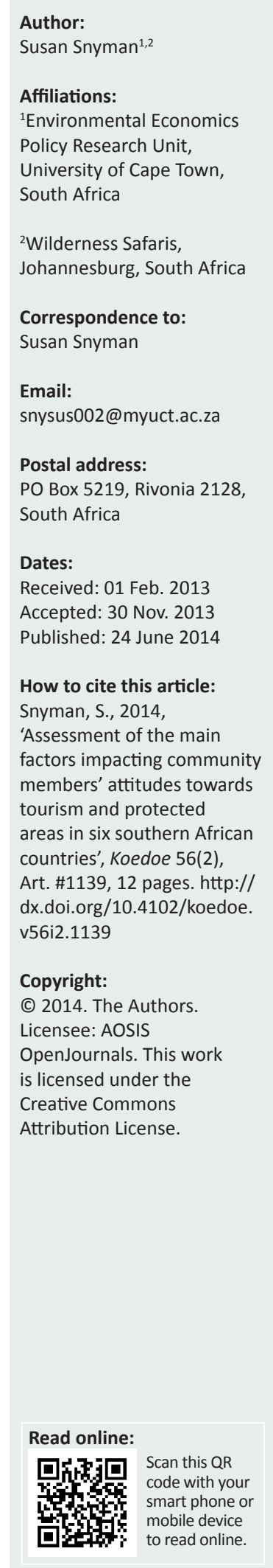

In southern Africa, many early conservation efforts from the late 1800s and early 1900s either displaced local communities or restricted their access to natural resources. This naturally affected community attitudes towards protected areas and efforts were later made to rectify growing tensions. In the last few decades of the 20th century, these efforts led to conservation and ecotourism models that increasingly included communities in the decision-making and benefit-sharing process in order to garner their support. Although the results of these policies were mixed, it is clear that the future success of conservation and, consequently, ecotourism in many areas will depend on the attitudes and behaviour of communities living in or adjacent to protected areas. Managing and understanding community expectations and attitudes under varying socio-economic circumstances will lead to more efficient, equitable and sustainable community-based conservation and ecotourism models. This study was based on 1400 community interview schedules conducted in Botswana, Malawi, Namibia, South Africa, Zambia and Zimbabwe, allowing for an accurate comparison of attitudes across countries, protected areas and communities. The results highlighted important demographic and socio-economic factors to consider in terms of understanding the attitudes of those living in and around protected areas. Suggestions were put forward for managing community relationships and garnering long-term support for protected areas and ecotourism.

Conservation implications: It was observed that, in general, community members living in or adjacent to conservation areas in southern Africa have an understanding and appreciation of the importance of conservation. Formal education was found to positively impact attitudes and human-wildlife conflict negatively impacted attitudes, highlighting important policy focus areas.

\section{Introduction}

It is clear that sustainable African conservation has to include local populations (Hoon 2004; Musumali, Larsen \& Kaltenborn 2007). Many have argued that if communities receive benefits from protected areas (PAs) and ecotourism they will tend to hold positive attitudes towards conservation as a land use and to care for the natural resources in their area (Currie 2001; Emptaz-Collomb 2009; Hulme \& Murphree 2001; McNeely, in Groom \& Harris 2008; Wang \& Pfister 2008; Waylen et al. 2009). Ecotourism allows local communities to receive benefits from conservation, both directly, through wages and salaries, and indirectly, as suppliers of goods and services. Numerous authors have argued that community support is critical to the long-term success of ecotourism operations and their associated PAs (Alexander 2000; Allendorf et al. 2006; Chandralal 2010; Gillingham \& Lee 2003; Makindi 2010; Nepal 2002; Newmark et al. 1994; Sifuna 2010). An analysis of community attitudes towards PAs across southern African would highlight the determinants of community support. Such information may encourage governments and ecotourism operators to focus on these factors in policy decisions. Although PAs and ecotourism are interlinked, community attitudes towards them may be sensitive to the direct costs and benefits of ecotourism, particularly employment and human-wildlife conflict.

Managing community expectations of ecotourism requires an understanding of the factors driving their attitudes. Education and awareness-raising programmes also benefit from an understanding of community attitudes (Allendorf et al. 2006; Chidakel 2011; Sifuna 2010; Simelane, Kerley \& Knight 2006). As Emerton (1999) pointed out, benefit distribution is a necessary, but not sufficient, condition for communities to engage in wildlife conservation (Snyman 2012a). The understanding of local residents' attitudes, by the managers of PAs and eco-lodges, will naturally affect their interactions with the community and it is hoped that this understanding will allow more focused planning in PAs and associated ecotourism operations. 
The specific objectives of the present study were to, (1) enrich the tourism and PA literature with an analysis of factors impacting rural community members' attitudes to tourism and PAs across six southern African countries and (2) provide useful policy options and practices for PA and ecotourism managers.

From these objectives three research questions emerged:

- What demographic and socio-economic factors drive rural community members' attitudes towards tourism and PAs?

- How do rural community members' attitudes differ across six southern African countries?

- What policy implications emerge from an understanding of factors impacting community members' attitudes?

\section{Conceptual framework and literature review}

Following Allport and McDougall and Munro (both in Wang \& Pfister 2008:85) we shall treat 'attitudes' as 'respondents' particular feelings and perceptions towards the stated questions relating to tourism and/or conservation'. Wang and Pfister (2008) found that examinations of attitudes towards tourism showed that these are influenced by people's values and personality and are therefore slow to change. They are also influenced by factors invisible to outsiders (Allendorf $e t$ al., in Waylen et al. 2009) making them difficult to observe or understand.

In addressing individual community members' attitudes, social exchange theory assumes that potential beneficial outcomes will create positive attitudes towards tourism (Andereck et al. 2005; Teye, Sönmez \& Sirakaya 2002). The theory postulates that individuals perceiving net benefits from an exchange are likely to view it positively and those perceiving net costs are likely to view it negatively (Snyman 2012a). This approach is supported by numerous studies which showed that residents dependent on tourism for support, or who perceive it offering net personal benefits, tend to view its impacts more positively than others (Brunt \& Courtney and Child, in Groom \& Harris 2008; various sources, in Andereck et al. 2005:1061; Shibia 2010; Walpole \& Goodwin 2001; Wang \& Pfister 2008).

The fact that people with lower household incomes are often less supportive of PAs and tourism is largely explained by needs theories. Such theories argue that an individual's basic needs are attended to first before higher needs such as supporting community, conservation or tourism initiatives (Doyal \& Gough and Maslow, in Emptaz-Collomb 2009). Emptaz-Collomb (2009) stresses that it would therefore be prudent for companies or individuals engaged in such initiatives to assist in improving the lives of local people through improving access to and the quality of education, health, transport and communication. In the long run, this would create a more supportive environment for tourism and conservation projects and ensure their sustainability. Government, non-governmental organisations (NGOs) and the private sector can all play a role in this through infrastructural and other development projects.

The importance of understanding attitudes lies in their theoretical connection with behaviours (Manfredo et al., in Lepp \& Holland 2006). The links between attitudes and behaviours are, however, not automatic (Scanlon \& Kull 2009). Even though Nunkoo and Ramkissoon (2011) found that residents in their Mauritian study engaged in behaviours congruent with their attitudes, this will not always be the case.

Although past research has shown that many communities hold positive attitudes towards conservation (Alexander 2000; Currie 2001; De Boer \& Baquete 1998; Mehta \& Heinen 2001; Sekhar 2003; Weladji, Moe \& Vedeld 2003) and ecotourism development (Chandralal 2010; Lepp 2007; Mehta \& Kellert 1998), there are a number of different factors affecting attitudes. Some studies (Gadd 2005; Lepp \& Holland 2006; Rodriguez 2008) have also found that communities, for varying reasons, may hold negative attitudes towards conservation.

Some studies have also not found a correlation between economic benefits from tourism and positive attitudes to conservation (Stem et al. 2003; Walpole \& Goodwin 2001) or suggested that economic benefits alone were insufficient to encourage conservation (Stem et al. 2003; Stronza \& Pégas 2008). Stem et al. (2003) and Stronza and Gordillo (2008:450) found that non-economic benefits, such as new skills, broader experiences in managing projects and people, ideas exchange, expanded circles of contacts, empowerment and support for community efforts, could also influence attitudes towards PAs and tourism. These non-economic benefits are, however, often more difficult to measure and assess.

Creating and maintaining positive attitudes towards PAs is especially important when other mechanisms for changing behaviour, such as regulation, are inappropriate or ineffective (Waylen et al. 2009). Over the years, regulation has often failed to ensure conservation success and the resultant need for a more appropriate and effective means of ensuring conservation has arisen.

In summary, studying community members' attitudes towards tourism and PAs is important for a number of reasons (Snyman 2012a):

- It can disclose whether or not negative attitudes exist towards a PA and/or tourism operation, which, in some cases, may help to explain behaviour (Lepp \& Holland, in Anthony 2007).

- It can inform policymakers and managers about which factors influence attitudes and this can assist with prioritising avenues for action (Anthony 2007; BrowneNuñez \& Jonker 2008).

- It can reveal opportunities for improving relationships and outreach programmes with communities living adjacent to PAs (Anthony 2007). 
- It can assist in developing appropriate benefit-sharing and cost-minimising programmes for communities based on their attitudes and experiences.

- It can highlight areas important for education and training programmes.

Overall, there is widespread consensus that community attitudes matter and these attitudes may vary over time and be influenced by various factors (e.g. changing incomes, land management arrangements, etc.) (Andereck \& Vogt 2000; Anthony 2007; Gillingham \& Lee 1999). Factors such as the level of education, recent experiences and degree of politicisation may also play a role. In an attempt to capture the relevant issues, this article looks at the impact of a number of socio-economic variables on community attitudes across different countries. Despite the many attitude studies that have been conducted, they are not always comparable as they have been conducted under different circumstances and with different measurement tools. This study was however conducted consistently over six study countries allowing for a more accurate comparison of attitudes across countries, PAs, tourism operations and communities.

\section{Research method and design}

In this study (adapted from Snyman 2012a, 2013) extensive socio-economic interviews were conducted in over 30 rural communities, covering more than 16 different ethnic groups and an average of approximately $25 \%$ of households in each study village (ranging from $10 \%$ to $84 \%$ ). The selection of study sites was dictated by the presence of a communityecotourism relationship or partnership, or because the community lived in or adjacent to the conservation or PA where the ecotourism operation was located, or a combination of these (in this study all ecotourism operations were owned or managed by Wilderness Safaris, see http:/ / www.wilderness-safaris.com). Conservation areas need not be government owned, but can include areas owned and/ or managed by communities, private individuals, NGOs or companies (Makindi 2010). The common feature of the areas covered in this study is that all have been specifically set aside for conservation. At one extreme, this involved the total relocation of local people formerly living in the area (e.g. the Makuleke community in South Africa); at the other extreme are conservation areas in which people still live and have access to the natural resources (e.g. the Namibian conservancies). Few of the study sites had accurate or recent maps of households, dictating other means of sample size selection. Sample sizes varied with the size of the community being surveyed. An attempt was made to interview at least $10 \%$ of households in all adjacent communities. Logistically, however, this was not always possible. If the survey area was small, then the majority of the households in the area were interviewed. If the survey area was large, then for logistical reasons, a subset of villages and households was selected. Household numbers were obtained from the latest census figures and/or from the respective Headman, Chief or Community Trust. Households were selected randomly, either by walking through the village interviewing every second household (or the next household where someone was available) or interviewing a household member in a public area, for example, a local shop or meeting area. In total, 1400 community interviews were conducted in rural villages either within or adjacent to PAs (see Table 1). Attempt was made to interview the household head, but if they were not available, then either the spouse, or next oldest person in the household was interviewed.

TABLE 1: Details of communities surveyed in each country.

\begin{tabular}{|c|c|c|c|c|c|}
\hline Country & $\begin{array}{l}\text { Land ownership of related ecotourism } \\
\text { camps }\end{array}$ & List of communities surveyed & $\begin{array}{l}\text { Ethnic groups } \\
\text { surveyed }\end{array}$ & $\begin{array}{l}\text { Associated conservation } \\
\text { or protected area }\end{array}$ & $\begin{array}{l}\text { Number of interviews } \\
\text { conducted }\end{array}$ \\
\hline Botswana & $\begin{array}{l}\text { Kwedi Concession where camps are situated } \\
\text { is owned by the Okavango Community Trust } \\
\text { (Community concession). Community receives } \\
\text { lease fee payments from Wilderness Safaris. }\end{array}$ & $\begin{array}{l}\text { Okavango Community Trust } \\
\text { villages - Seronga, Gunotsoga, } \\
\text { Beetsha, Eretsha, Gudigwa }\end{array}$ & $\begin{array}{l}\text { Bayei, Hambukushu, } \\
\text { Basarwa, Bakgalagadi }\end{array}$ & Okavango Delta & 261 \\
\hline Malawi & $\begin{array}{l}\text { Various national parks own the land } \\
\text { (Government). }\end{array}$ & $\begin{array}{l}\text { Villages in Balaka District, } \\
\text { bordering Liwonde National Park }\end{array}$ & $\begin{array}{l}\text { Lomwe, Yao, Nyanja, } \\
\text { Tumbuka, Tonga }\end{array}$ & Liwonde National Park & 251 \\
\hline \multirow[t]{2}{*}{ Namibia } & $\begin{array}{l}\text { Ministry of Environment and Tourism runs } \\
\text { Skeleton Coast National Park (Government). } \\
\text { Voluntary community levies are paid to the } \\
\text { four adjacent conservancies. }\end{array}$ & $\begin{array}{l}\text { Okondjombo Conservancy; } \\
\text { Purros Conservancy; Sanitatas } \\
\text { Conservancy; Orupembe } \\
\text { Conservancy }\end{array}$ & $\begin{array}{l}\text { Herero, Himba, } \\
\text { Damara, } \\
\text { Riemvasmaker }\end{array}$ & $\begin{array}{l}\text { Skeleton Coast National } \\
\text { Park }\end{array}$ & 271 \\
\hline & $\begin{array}{l}\text { For Palmwag Lodge: Ministry of Environment } \\
\text { and Tourism as well as the Big Three } \\
\text { Conservancies (Government and conservancy } \\
\text { payments). For Doro Nawas Camp a joint } \\
\text { venture with the Doro !Nawas Conservancy. } \\
\text { For Damaraland Camp: a joint venture with } \\
\text { Torra Conservancy. }\end{array}$ & $\begin{array}{l}\text { Torra, Anabeb and Sesfontein } \\
\text { Conservancies }\end{array}$ & $\begin{array}{l}\text { Herero, Himba, } \\
\text { Damara, } \\
\text { Riemvasmaker }\end{array}$ & $\begin{array}{l}\text { Palmwag Concession } \\
\text { area }\end{array}$ & 271 \\
\hline \multirow[t]{2}{*}{ South Africa } & $\begin{array}{l}\text { iSimangaliso Wetland Park owns the land. } \\
\text { Joint venture partnership between } \\
\text { Wilderness Safaris and the Mpukane } \\
\text { Community. }\end{array}$ & Mpukane Community & Zulu & $\begin{array}{l}\text { iSimangaliso Wetland } \\
\text { Park }\end{array}$ & 329 \\
\hline & $\begin{array}{l}\text { Tripartite agreement between the Makuleke } \\
\text { community, Wilderness Safaris and South } \\
\text { African National Parks (Community, private } \\
\text { sector and government). }\end{array}$ & $\begin{array}{l}\text { Three villages in the Makuleke } \\
\text { community }\end{array}$ & Tsonga & Kruger National Park & 329 \\
\hline Zambia & National Parks owns the land (Government). & $\begin{array}{l}\text { Villages in the Malama Chiefdom } \\
\text { adjacent to South Luangwa } \\
\text { National Park }\end{array}$ & $\begin{array}{l}\text { Kaonde, Senga, } \\
\text { Chewa, Ngoni, } \\
\text { Bemba \& Nyanja }\end{array}$ & $\begin{array}{l}\text { South Luangwa } \\
\text { National Park }\end{array}$ & 67 \\
\hline Zimbabwe & National Parks owns the land (Government). & $\begin{array}{l}\text { Villages in Tsholotsho District } \\
\text { adjacent to Hwange National Park }\end{array}$ & $\begin{array}{l}\text { Ndebele, Kalanga, } \\
\text { Lozi, Shona }\end{array}$ & $\begin{array}{l}\text { Hwange National } \\
\text { Park }\end{array}$ & 221 \\
\hline
\end{tabular}

Source: Adapted from Snyman, S., 2012a, 'Ecotourism joint ventures between the private sector and communities: An updated analysis of the Torra Conservancy and Damaraland Camp, Namibia', Tourism Management Perspectives 4, 127-135. http://dx.doi.org/10.1016/j.tmp.2012.07.004 
As the concept of community is central to the analysis in this article the term needs to be clarified. For the purposes of this article, we follow Borrini's (as cited in Borrini-Feyerabend, Kothari \& Oviedo 2004:9) description of it as 'a human group sharing a territory and involved in different but related aspects of livelihoods - such as managing natural resources, producing knowledge and culture, and developing technologies and practices', whilst a local community is a group who interact regularly or who influence one another's daily lives. In this study, such local communities may be mobile, permanently settled or semi-nomadic such as the Himba people of north-west Namibia. The communities are found living either within or adjacent to the PA, or in some cases, having left the PA, are now living further afield (e.g. the Makuleke community which is located two hours' drive from Pafuri Camp, but is still impacted by it). All communities described in this article are either directly or indirectly affected by the conservation and ecotourism strategies in their area, whilst their activities, in turn, impact nearby PAs and ecotourism operations. The camps associated with the study communities were all ecotourism camps in terms of their location and the activities offered.

Defining ecotourism and its relationship to conservation is also contextually important at this stage. In summarising the literature, De Witt, Van der Merwe and Saayman (2011:1139) suggest that the key principles of ecotourism are that it should foster a genuine interest in nature, contribute to conservation, respect and conserve local culture, make nonconsumptive use of natural resources, yield benefits to the local community and create tourist awareness of conservation and local community issues. Based on this definition, ecotourism in this article is taken to include activities which are nature-based and culture-based, sustainable, promote conservation and provide benefits to local people in the area. It is therefore not simply tourism that is based on the sale of access to an interesting natural area, but tourism that also provides benefits to local communities (Snyman 2013).

The interviews were conducted by both male and female interviewers and local translators were used in circumstances where the respondent could not speak or understand English. The interview schedules contained questions relating to demographics, social welfare and living standards, education, employment patterns, income and expenses, health and safety and attitudes toward tourism and conservation. This article focuses on the sections relating to attitudes. Each interview was conducted verbally, with the interviewer completing the questionnaire during the interview. Each interview took approximately $20 \mathrm{~min}-$ 45 min depending on the respondent's educational level and whether or not translation was required. The interview schedule consisted of a structured set of questions, with the majority being close-ended and some having the option for further explanation.

Communities associated with a single ecotourism enterprise, Wilderness Safaris (WS), were surveyed in this study because it was the only ecotourism company that had parallel ecotourism operations, operating according to a standard policy framework, over the six Anglophone countries in the region. The use of a single company made for ease of comparison because the head office imposes a consistent management style over its different camps in southern Africa. The company itself wished to quantify the impact of its ecotourism operations on rural communities and gave the author access to its camps and staff and to the communities with whom they engage.

The process followed does, however, mean that some caveats attach to this research:

- Although the camps and communities were diverse (with varying land management systems, ethnic groups and tourism camp price ranges), as only one ecotourism operator was included in the analysis, there could be limitations to the generalisability of the research.

- The author was employed by WS to conduct a study on the impact of the company's activities on rural communities. This study was, however, performed as an independent researcher looking to discover the realities of ecotourism and community development and was in no way influenced by the company.

- Local residents would have associated interviewers with WS because of the use of WS vehicles in some areas and through the introduction process. This may have biased responses to questions about WS. It is however impossible to predict the direction of the bias a priori; some respondents may have been strategically negative in order to ensure changes or positive in order to win favour with the private sector operator in the area (Allendorf et al. 2006). The results showed both positive and negative responses in all areas and many respondents were clearly comfortable expressing negative responses.

- The presence of the researcher during the administration of the interview schedule may have influenced some respondents and their answers to attitudinal questions regarding tourism and conservation. The bulk of the interview schedule was, however, socio-economic in nature and this should not have proven problematic. There remained the risk of strategic bias. When it was felt that this was occurring, the author re-iterated to the respondent that the interview was anonymous and honest answers were required.

All data collected were analysed using SPSS version 12 (2004) and STATA version 10.2 (2008), as well as a combination of descriptive statistics, $t$-tests and Probit models.

\section{Results}

Table 2 summarises the respondents' demographic details in order to provide context to the other results. These results are both aggregated across the southern African region and, in some cases, disaggregated by country to show specific country nuances. Table 3 shows the results for the tourism and conservation attitudes by location. Overall, the Zambian community respondents held the most positive attitudes to tourism and conservation. This is most likely because there 
were few employment opportunities in the area other than ecotourism or with the Zambian Wildlife Authority.

The importance of tourism and conservation in these remote, rural areas is highlighted by the percentage of respondents (45\%) who had family members working in tourism and/or conservation. This result does, however, need to be interpreted with caution in terms of total employment impact. There is a risk of double-counting, as many village respondents are related and a number of separate households may have been referring to the same employed family member. In all, $87 \%$ of community respondents felt that conservation was important, despite $83 \%$ of them having problems with wild animals.

\section{Reasons given for the importance of conservation}

Respondents who felt that conservation was important were asked for their reasons. A number of different rationales emerged (see Table 4). Many respondents said that it was important for tourism. Other reasons included: for their children and/or the future and to be able to use the natural resources in the future for food, firewood, et cetera. Some respondents said because the 'trees bring rain and/or prevent wind'. Some respondents said that conservation was important for tourism, but not for people's crops or livestock and others said that it was important to conserve trees and plants, but not animals because they were dangerous. A number of respondents gave more than one reason and others said that they knew it was important (often because they had been told at school), but did not know why. In some areas, respondents said it was important because the government said so.

\section{Probit models for tourism and protected area attitudes}

Probit models were run for each of the attitude questions. The demographic variables in the Probit were chosen as a result of a descriptive statistical analysis and an extensive literature review of factors found to impact community attitudes. Table 5 presents the Probit results, reporting marginal effects for each attitude question.

Although factors affected attitudes differently, there was a trend observed in terms of the impact of education on attitudes, with respondents reporting higher levels of

TABLE 2: Summary of respondents' demographic characteristics.

\begin{tabular}{|c|c|c|c|c|c|c|c|c|}
\hline \multirow[t]{2}{*}{ Country sampled } & \multirow{2}{*}{$\begin{array}{l}\text { Average age of } \\
\text { respondent } \\
\text { (in years) }\end{array}$} & \multicolumn{2}{|c|}{ Gender of respondent } & \multirow{2}{*}{$\begin{array}{l}\text { Average number } \\
\text { in the household }\end{array}$} & \multirow{2}{*}{$\begin{array}{l}\text { Average number } \\
\text { of children }\end{array}$} & \multicolumn{2}{|c|}{ Gender of the household head } & \multirow{2}{*}{$\begin{array}{l}\text { Average number } \\
\text { of years formally } \\
\text { educated }\end{array}$} \\
\hline & & Male (\%) & Female (\%) & & & Male (\%) & Female (\%) & \\
\hline Botswana & 33.45 & 43 & 57 & 6.59 & 2.36 & 43 & 57 & 6.59 \\
\hline Malawi & 38.73 & 39 & 61 & 4.58 & 4.15 & 78 & 22 & 3.19 \\
\hline Namibia & 36.84 & 55 & 45 & 8.21 & 3.43 & 57 & 42 & 5.14 \\
\hline South Africa & 44.30 & 31 & 69 & 6.39 & 3.46 & 62 & 37 & 6.90 \\
\hline Zambia & 40.88 & 27 & 73 & 5.99 & 4.73 & 69 & 31 & 5.66 \\
\hline Average & 39.53 & 40 & 60 & 6.48 & 3.58 & 65 & 35 & 5.78 \\
\hline
\end{tabular}

TABLE 3: Attitudes towards tourism and conservation by sampled communities.

\begin{tabular}{|c|c|c|c|c|c|c|c|c|c|c|c|c|c|c|c|c|}
\hline \multirow[t]{2}{*}{$\begin{array}{l}\text { National communities } \\
\text { sampled }\end{array}$} & \multicolumn{2}{|c|}{$\begin{array}{l}\% \text { who felt that } \\
\text { there had been a } \\
\text { positive change } \\
\text { in the villages } \\
\text { because of tourism }\end{array}$} & \multicolumn{2}{|c|}{$\begin{array}{l}\% \text { who felt } \\
\text { that tourism } \\
\text { creates jobs } \\
\text { for local } \\
\text { people }\end{array}$} & \multicolumn{2}{|c|}{$\begin{array}{l}\% \text { who felt } \\
\text { that tourism } \\
\text { reduces } \\
\text { poverty in the } \\
\text { area }\end{array}$} & \multicolumn{2}{|c|}{$\begin{array}{c}\text { \% who } \\
\text { felt that } \\
\text { conservation } \\
\text { was important }\end{array}$} & \multicolumn{2}{|c|}{$\begin{array}{c}\text { \% who } \\
\text { have family } \\
\text { employed in } \\
\text { tourism or } \\
\text { conservation }\end{array}$} & \multicolumn{2}{|c|}{$\begin{array}{c}\% \text { who } \\
\text { collect natural } \\
\text { resources from } \\
\text { the conservation } \\
\text { area }\end{array}$} & \multicolumn{2}{|c|}{$\begin{array}{l}\text { \% who had } \\
\text { problems } \\
\text { with wild } \\
\text { animals } \dagger\end{array}$} & \multicolumn{2}{|c|}{$\begin{array}{c}\% \text { who would } \\
\text { like to visit the } \\
\text { conservation } \\
\text { area }\end{array}$} \\
\hline & $\%$ & $n$ & $\%$ & $n$ & $\%$ & $n$ & $\%$ & $n$ & $\%$ & $n$ & $\%$ & $n$ & $\%$ & $n$ & $\%$ & $n$ \\
\hline Botswana communities & 36 & 213 & 74 & 234 & 70 & 232 & 84 & 250 & 50 & 245 & Missing & - & 92 & 261 & Missing & - \\
\hline Malawi communities & 31 & 234 & 49 & 234 & 37 & 237 & 80 & 246 & 22 & 249 & 10 & 251 & 94 & 251 & 63 & 242 \\
\hline Namibia communities & 44 & 172 & 68 & 208 & 42 & 164 & 93 & 258 & 57 & 265 & 92 & 271 & 55 & 271 & Missing & - \\
\hline Zambia communities & 75 & 65 & 93 & 65 & 78 & 62 & 96 & 67 & 81 & 67 & 0 & 67 & 99 & 67 & 94 & 67 \\
\hline Zimbabwe communities & 75 & 182 & 70 & 190 & 70 & 181 & 86 & 200 & 56 & 218 & 5 & 221 & 96 & 221 & 92 & 221 \\
\hline Community average $\S$ & 49 & 1103 & 69 & 1198 & 55 & 1066 & 87 & 1324 & 45 & 1373 & 24 & 1135 & 79 & 1400 & $85 !$ & $859 \$$ \\
\hline
\end{tabular}

Missing, these questions were not included in the survey for this country.

$\downarrow$ This question relates to human-wildlife conflict and whether or not respondents experienced crop or livestock losses from wildlife, or any other problems related to wildlife

$\dagger$, This question relates to human-wildlife conflict and whether or not respond

$\S$, The averages were calculated using the whole sample, not the averages for each country.

TABLE 4: Main reasons given for the importance of conservation by location.

\begin{tabular}{|c|c|c|c|c|c|c|}
\hline Country & Reason 1 & $\%$ & Reason 2 & $\%$ & Reason 3 & $\%$ \\
\hline Botswana & Tourism & 26 & Future and/or children & 9 & For income & 7 \\
\hline Malawi & Tourism & 46 & Future and/or children & 6 & For income & 5 \\
\hline Namibia & Tourism & 26 & $\begin{array}{l}\text { Meat from animals and/or firewood } \\
\text { from trees }\end{array}$ & 19 & Future and/or children & 15 \\
\hline South Africa & Future and/or children & 22 & Trees prevent wind & 16 & Natural resources & 10 \\
\hline Zambia & Tourism & 25 & Meat from animals & 15 & Benefits the community & 15 \\
\hline Zimbabwe & Did not specify a reason & 21 & $\begin{array}{l}\text { Use natural resources for thatching, } \\
\text { water, firewood, etc. }\end{array}$ & 14 & Tourism & 13 \\
\hline
\end{tabular}


TABLE 5: Probit results reporting marginal effects for each attitude question.

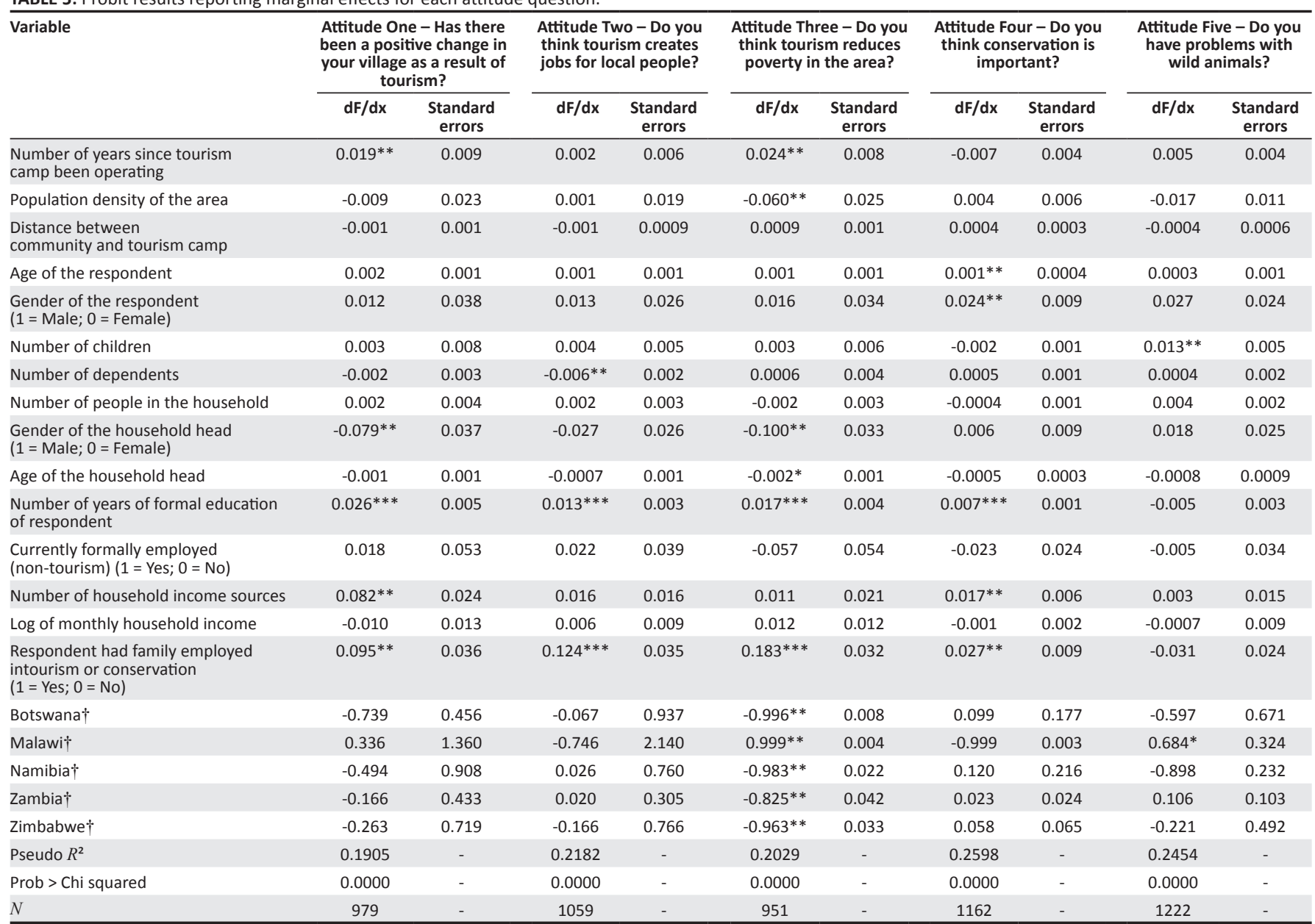

$* * *, * *$, and $*$ indicate significance levels at the $1 \%, 5 \%$ and $10 \%$ levels, respectively.

$\dagger$, Base country is South Africa.

formal education being more positive. This was statistically significant in four of the questions. Those who were more educated also had fewer problems with wild animals.

Statistically, demographic variables had varying impacts on attitudes. Age was however, surprisingly, positively related, suggesting that older respondents were more positive about tourism and PAs than younger respondents. With respect to age of the household head however, this relationship was largely negative, with respondents with older household heads being less positive about tourism and PAs.

Areas with higher population densities were shown to be less positive about tourism and PAs. Distance had mixed impacts on attitudes, as did the number of years that the tourism camp had been operating. Respondents with more household income sources tended to be more positive about tourism having a positive change in their village, as well as about conservation being important.

A consistent issue raised in all study communities was that of wild animals interfering with households' livelihoods and, in some cases, personal safety. One female respondent in Malawi told of a night she had been terrified inside her house with her children, whilst a bull elephant tried to push the
TABLE 6: Percentage of respondents who had problems with wild animals by location.

\begin{tabular}{lll}
\hline Country sampled & Sample size $(\boldsymbol{n})$ & $\begin{array}{l}\text { \% who had problems with } \\
\text { wild animals }\end{array}$ \\
\hline Botswana & 261 & 93 \\
Malawi & 251 & 94 \\
Namibia & 271 & 55 \\
South Africa & 329 & 61 \\
Zambia & 67 & 99 \\
Zimbabwe & 221 & 96 \\
\hline Average & $\mathbf{1 4 0 0}$ & $\mathbf{8 3}$ \\
\hline
\end{tabular}

house over to reach her maize stored inside. This highlights the real threat wildlife can pose to rural households and their livelihoods. Table 6 shows that across all communities surveyed, $83 \%$ of respondents had problems with wild animals at home.

Elephants were the most frequently mentioned animals (55\%) that caused problems, followed by lions $(28 \%)$. Other animals mentioned included cheetah, hippo, leopard, hyaena, baboon and jackal. In general, human-wildlife conflict (HWC) resulted in less positive attitudes towards ecotourism in the study areas.

Respondents who had family employed in tourism or conservation were generally observed to be more positive 
towards tourism and PAs and had fewer problems with wild animals. Having family employed in tourism or conservation positively impacted four attitude questions and could be because unemployment and poverty levels are high; having a family member employed in tourism or conservation therefore has a significant impact on a household and therefore on attitudes.

The country variable was significant in the 'reducing poverty' question only, indicating that, in general, communities across southern Africa did not differ significantly in their attitudes towards tourism and PAs.

\section{Ethical considerations}

The interview schedule was approved by the University of Cape Town's Ethics Committee. All respondents were told the reason for the study and signed a written consent form prior to the interviewer beginning the interview. Respondents were told that the interview schedules were confidential and their participation in answering all questions was voluntary. This resulted in some questions not being answered. Nonresponse to questions did not cluster on particular questions, as no particular question had a greater non-response rate than any other question.

\section{Trustworthiness}

Although every effort was made to ensure the interviews and data analysis were conducted correctly, certain assumptions and limitations of the research necessarily arise, which should be factored into the data analysis and interpretation.

\section{Reliability}

Cross-cultural research can have limitations in terms of respondents reacting or answering differently because of the presence of an expatriate working in a developing country that was previously colonised (Bruyere, Beh \& Lelengula 2009). It was hoped that the use of local translators (who received informal training from the author) would help minimise this limitation. The author and other interviewers (where not local) also made efforts to learn some of the local languages and customs, to greet respondents in their own language and to help them feel relaxed.

De Boer and Baquete (1998) warned that formal questionnaires become a drawback when people are unwilling to express negative opinions or attitudes to a third party, in particular where interviewees are reluctant to confess to illegal exploitation practices, such as snaring or collecting plants in a restricted area. Questionnaires are, however, a cost-effective method of research. This needs to be kept in mind when analysing the data collected on opinions and attitudes to tourism and conservation in the present study. That negative attitudes were expressed by some respondents suggests that they did not feel constrained. In order to minimise bias and inaccurate information, respondents were also informed at the beginning of the interview that it was anonymous, was part of a research study, and that their responses would be aggregated and impossible to identify in the larger study.

Interviews run a number of other risks including the researcher leading the respondent, variation in the delivery of the survey between interviewers, respondent anticipation or desire to please the researcher and discrepancies between what people report and what they actually do or feel (De Boer \& Baquete 1998; Gadd 2005). Despite this, surveying attitudes and quantifying them is necessary if one is to compare attitudes towards conservation and ecotourism in different regions or within the same region over time (Gadd 2005). Every effort was made to keep the interviews uniform and to ask questions in such a manner as to reduce bias or at least keep it consistent. In order to render any existing bias relatively constant, the author conducted over 1000 of the interviews herself. Eight other interviewers assisted across the six countries.

\section{Validity}

The sample size was not standardised in all study countries because of logistical constraints in some areas where communities were large. These differences in the percentage of the community interviewed could result in some issues relating to external validity. It was however felt that all sample sizes were sufficient in the areas surveyed and no new information was found after a certain percentage (approximately 100 households) of the community had been interviewed.

The Zambian sample is included in the analysis because, despite being small, it was felt to be relevant and representative of the area where the interviews were conducted. Inferences drawn from the Zambian results should however be viewed with caution.

\section{Discussion}

The present study analysed the impact of various demographic and socio-economic variables on attitudes of community members in six southern African countries and, as in past studies, (Allendorf et al. 2006; Simelane et al. 2006) found mixed results relating to various factors.

Individual's attitudes, although generally long term, can change over time and also vary between and within different communities and countries. There are a number of factors that cannot be controlled or manipulated, so it is important that policy is aimed at those factors that can, to some extent, be influenced - for example, education, land ownership, et cetera.

In general, community members in this study felt that tourism creates employment and can help reduce poverty. If tourismrelated jobs were to disappear in an area (for example in the Zambian study area where tourism is one of few employers), it is unlikely that people would feel as positive about tourism and PAs in the future. This highlights the importance 
individuals attach to tourism in terms of employment, household income, et cetera. It is critical that this is managed in an appropriate manner to ensure that expectations are met and that there is not large-scale disappointment on the part of communities. This is highlighted by the fact that in communities where tourism had been operational for longer, respondents were less positive about conservation than those areas where tourism was new.

Allendorf (2007) highlighted that although there has been little attention given to the importance of non-economic benefits that residents may value in developing countries, studies indicate that people do value PAs for non-economic reasons, such as ecosystem services, for the benefit of future generations and the conservation of wildlife. This was supported by the findings in the present study. Although many respondents felt that conservation was important because of the income to be derived from it through employment and tourism, many felt that it was important for their children and future generations, as well as for the wood, thatch and food it provides.

As found in the present study, various other studies have found differing results relating to the impact of demographic variables on attitudes towards tourism and conservation (Akyeampong 2011; Allendorf et al. 2006; Baral \& Heinen 2007; Currie 2001; De Boer \& Baquete 1998; Gadd 2005; Gillingham \& Lee 1999; Kideghesho, Røskaft \& Kaltenborn 2007; Larson 2010; Mbaiwa \& Stronza 2011; Mehta \& Heinen 2001; Sarker \& Røskaft 2010; Sekhar 2003; Shibia 2010; Stem et al. 2003; Tessema et al. 2007; Teye et al. 2002; Weladji et al. 2003). It appears, therefore, that it is difficult to use demographic variables to predict attitudes. There are, however, some areas of commonality in terms of demographics that can be used as potential predictors.

Other studies (Anthony 2007; Currie 2001) have largely found that younger respondents hold more positive attitudes towards tourism and PAs. This may be because many younger people have more education than older people, are less reliant on natural resources and therefore less affected by a lack of access to them and/or have alternative livelihoods that reduce the risk that they face. Age was significant only in the 'conservation important' attitude, with a positive coefficient, indicating that as age increases, there was an increase in the predicted probability of having a positive attitude. This contradicts past research relating to the impact of age.

The number of children was only significant in the 'problem animal' attitude question, with a positive relationship. This could be because respondents with more children perceived more problems with wild animals, as any conflict would negatively affect them as they had more mouths to feed.

Communities living in or adjacent to PAs frequently incur direct costs associated with living next to wildlife, such as damage to crops, loss of livestock and, occasionally, loss of human life. Other costs associated with wildlife include the additional direct cost of guarding crops and livestock by paying someone to look after them or the opportunity cost of protecting them by giving up one's time which could have been put to a more productive use. This often results in a disruption to children's schooling as they are kept out of school to guard household fields (pers. obs. author, December 2009). Logic implies that those who are negatively impacted by wildlife are likely to have less positive attitudes towards conservation and consequently ecotourism. This is detrimental to the long-term success of PAs and ecotourism and therefore requires attempts to mitigate HWC in rural areas. In countries where there was a high percentage of respondents who had problems with wild animals combined with less positive attitudes (e.g. Malawi), it is even more important that the surrounding communities receive benefits from ecotourism and conservation, or measures to mitigate HWC.

Hill (2004) argues that people who believe that they do not have control over a conflict situation are often more likely to inflate their perceptions of risk and Dublin and Hoare (2004:274) emphasise that it is often the potential for suffering large losses, especially at harvest time, that is a major factor influencing rural communities' attitudes, rather than actual losses. This could explain the high incidence of HWC expressed in the surveys in the present study. The close-knit community life of many rural African villages could also result in an exaggeration of HWC based on the perceptions of residents, rather than the actual number of incidences (Romañach, Lindsey \& Woodroffe 2007; Woodroffe, Thirgood \& Rabinowitz 2005).

In general, respondents who said they had problems with wild animals were found to have less positive attitudes towards tourism and conservation. Walpole and Thouless (2005:130) highlight that tourism will only improve tolerance towards wildlife where the benefits of tourism actually reach those bearing the costs of living with wildlife and where the local communities can understand and act upon the linkages between tourism benefits and wildlife conservation. Those bearing the costs are frequently not the same people receiving the benefits and this needs to be taken into consideration for long-term sustainability (Walpole \& Thouless 2005).

Based on past studies (Groom \& Harris 2008; Mehta \& Kellert 1998), it was assumed that those with higher monthly household incomes would have more positive attitudes towards tourism and PAs. This assumption is based on the fact the wealthier households have the 'luxury' of being able to either enjoy the tourism, PAs and/or are not as greatly affected by the negative impacts of conservation, for example HWC, loss of access to natural resources, et cetera. Income had mixed effects on attitudes in this study and suggests that household wealth is not always a driver of positive attitudes.

Of importance to policymakers is that Groom and Harris (2008:250) found in their Kenyan study that although financial 
incentives from wildlife can improve community attitudes towards wildlife and conservation, the actual distribution of benefits is more important in shaping attitudes. This is supported by the results from the Torra Conservancy in Namibia, where respondents' attitudes were still (i.e. in 2009) influenced by a dividend payout in 2003 (see Snyman 2012a). The lack of consistency of the overall importance of household income as a determinant of attitudes in the Probit models suggests that income, as an incentive, is not the only incentive that matters to these communities.

Past studies have found that increased education impacted positively on attitudes towards tourism and PAs (see Chidakel 2011; Larson 2010; Shibia 2010; Tessema et al. 2007; Teye et al. 2002). Teye et al. (2002), in their Ghanan study, surmised that a more positive attitude towards tourism by more educated people could be explained by the fact that much has been written in English regarding the benefits of tourism in both print and electronic media, therefore educated people would be more familiar or aware of the potential benefits than those with less education. Overall in the present study, formal education was found to have a statistically significant positive impact on individual's attitudes to tourism and PAs, highlighting the importance of formal education in terms of garnering support from rural communities. The benefits of formal education are numerous in terms of long-term poverty reduction, as well as biodiversity conservation (see Snyman 2012c).

One would surmise that if a respondent had a family member, or in the case of the community respondents, was themselves, employed in tourism and/or conservation, then they would have more positive attitudes towards tourism and PAs. This is premised on the fact that they, or their family members, would be receiving direct, tangible benefits from tourism and/or PAs and would therefore be more positive towards it. This premise was supported by the results in this study. In fact, having a family member employed in tourism or conservation was one of the most significant variables in a number of the analyses. This illustrates that it is not necessarily required that someone has to be receiving direct benefits themselves to be aware of the benefits that can result from tourism and PAs.

\section{Conclusion}

It is frequently the vulnerability of poorer households and the risks they face that leads to less positive attitudes towards tourism and PAs. As discussed, the costs that communities have to bear are often high. If there are no concomitant benefits associated with these costs, then it is unsurprising that households would hold negative attitudes towards PAs and the associated tourism operations in the area.

Not only are there numerous direct factors affecting people's attitudes to tourism and PAs, they may also be influenced by costs and benefits that accrue to others, including those in different households (Emerton, in Sandbrook \& Adams 2012). This would explain why some households, who are not directly benefiting from, or negatively affected by, tourism or PAs, still hold certain attitudes towards it.

A factor that was shown to affect attitudes to conservation and that can be managed in order to ensure future positive attitudes was the length of operation of the ecotourism camp in the area. In general, the longer the camp had been open, the more negative respondents were about conservation; although, they interestingly tended to be more positive about tourism. This does not bode well for the long-term success of PAs and needs to be addressed. The main reason for this is likely because of unmet expectations, unfulfilled promises and high levels of HWC. The management of community expectations and benefit distribution before an ecotourism camp starts operating, as well as during the operational phase, including realistic goal setting, is important to the long-term success of ecotourism in PAs. It will help to reduce negative attitudes that can result from unmet expectations and the consequent dissatisfaction of communities living adjacent to PAs.

Formal employment of any kind was shown to have a largely positive impact on attitudes as it allows a diversification of household livelihoods and reduces the risk they face. The important point to note is that there are few formal employment opportunities in these remote rural areas, other than in ecotourism.

The results of this article highlight the diverse array of factors affecting people's attitudes towards ecotourism and PAs. Monetary benefits from ecotourism alone will not serve to improve local people's attitudes towards ecotourism and PAs, as there are a number of factors shaping attitudes. These include receipt of tangible, as well as intangible benefits, demographic factors, local economic situation, past beliefs, cultural beliefs, land ownership systems, population density and the diversity of livelihood strategies available to households in the area.

The more livelihood strategies people have available to them, the less dependent they are exclusively on natural resources for survival and livelihoods. It is premised that people will then value conservation and PAs more. Dependence on ecotourism as the sole livelihood can also be risky and vulnerable to external shocks. Ideally, ecotourism therefore needs to be part of a diverse livelihood portfolio. Conservation, for most rural Africans, is an investment for present and future value, with the main goal being the maintenance or enhancement of their livelihoods (Hulme \& Murphree 2001). Ecotourism can therefore assist communities in earning much-needed income, as well as assist them in conserving their natural resources in order to maintain or enhance other livelihoods. Such a scenario would however only apply in areas where communities have access to the natural resources in the area where the ecotourism camp operates (Snyman 2013). Communities who are excluded from PAs will require further incentives to conserve natural resources, as they will not be benefitting directly from their 
conservation. Global benefits to be derived from ecosystem services are also important and communities can play a role in this through watershed protection, preventing deforestation, et cetera.

The importance of education in terms of obtaining employment, as well as more positive attitudes is important in terms of the sustainability of tourism and conservation as land uses. Increasing access to formal education, improving education infrastructure, as well as implementing awareness and education campaigns in communities can serve to increase people's knowledge and awareness of PAs and tourism (Snyman 2013). This, in turn, may result in a greater willingness to accept the costs of living with wildlife and more positive attitudes towards PAs and tourism in the area.

Positive attitudes do not however necessarily suggest that behaviours will also promote conservation and tourism. Poor rural households face many economic and time constraints that can prevent them from supporting conservation (Snyman 2013). Parry and Campbell (in Emptaz-Collomb 2009:101) suggest that improving the living conditions and social welfare of rural people is therefore an important part of any conservation strategy. Ecotourism can play an important role here, through donations towards community development projects, tourism-related infrastructure developments, directly through wages and salaries and indirectly as suppliers of goods and services.

In summary, some implications for management drawn from this research include:

- In areas where government owns the land (in this study, national parks) and there is no contractual community involvement (e.g. Malawi, Zambia and Zimbabwe), there have to be benefits, both tangible and intangible, received by the community, as well as a mitigation of the negative impacts associated with conservation (i.e. HWC). Outreach programmes, introduced by the private sector tourism operator, in communities abutting the park could include educational programmes as well as social welfare projects. Such programmes would serve to link PAs and tourism directly to benefits (Snyman 2012b).

- Government, NGOs or the private sector need to raise awareness relating to ecotourism, conservation and PAs. Ecotourism operators can play an important role in this through environmental talks and conservation and tourism awareness-raising days in communities, as well as offering environmental lessons and game drives to community school children, as many have never been inside the PA adjacent to their homes (Snyman 2012b).

- There must be a clear, structured process of setting and managing expectations prior to an ecotourism operator starting in an area, as well as through the operational phases.

- Overall, it is not only important to maximise benefits to communities, there needs to be a concomitant process of minimising costs, as often there are more who will bear the costs than there are those who will benefit from the conservation and ecotourism in the area (Snyman 2012a).
- Alternative livelihoods (such as ecotourism employment) may assist in steering households away from absolute dependence on the consumptive use of natural resources for survival, which could, in turn, promote biodiversity conservation and long-term sustainable use, as well as positive attitudes (Snyman 2012b).

- Formal education is important and has been shown to influence attitudes. Improved educational infrastructure and improved access to education (e.g. scholarship programmes) should therefore be a priority in rural areas.

Managing community expectations, through an understanding of community members' attitudes under varying socio-economic conditions, will lead to more efficient, equitable and sustainable community-based conservation and tourism models. Also important for longterm sustainability is that, over and above this understanding, one needs to know what factors directly affect behaviours. Future research should focus on monitoring behaviours related to PAs, for example collection of natural resources, engagements with PA and ecotourism staff, et cetera. Positive community behavioural changes towards PAs and natural resources will ensure their long-term sustainability. A focus on formal education, improving social welfare and increasing the local linkages from ecotourism operations will go a long way in improving local community attitudes towards tourism and PAs.

\section{Acknowledgements Competing interests}

As stated above, the author was employed by ecotourism group, Wilderness Safaris, to conduct a study on the impact of the company's activities on rural communities. However, the study itself was performed by the author as part of her $\mathrm{PhD}$ research and in her capacity as an independent researcher looking to discover the realities of ecotourism and community development. It was in no way influenced by the company.

\section{References}

Akyeampong, O.A., 2011, 'Pro-poor tourism: Resident's expectations, experiences and perceptions in the Kakum National Park area of Ghana', Journal of Sustainable Tourism 19(20), 197-213. http://dx.doi.org/10.1080/09669582.2010.509508

Alexander, S.E., 2000, 'Resident attitudes toward conservation and black howler monkeys in Belize: The community baboon sanctuary', Environmental Conservation 27(4), 341-350.

Allendorf, T.D., 2007, 'Resident's attitudes toward three protected areas in Nepal', Biodiversity Conservation 16, 2087-2102. http://dx.doi.org/10.1007/s10531-0069092-z

Allendorf, T.D., Swe, K.K., Oo, T., Htut, Y., Aung, M., Aung, M. et al., 2006, 'Community attitudes towards three protected areas in Upper Myanmar (Burma)', Environmental Conservation 33(4), 344-352. http://dx.doi.org/10.1017/ S0376892906003389

Andereck, K.L. \& Vogt, C.A., 2000, 'The relationship between resident's attitudes toward tourism and tourism development options', Journal of Travel Research 39 27-36. http://dx.doi.org/10.1177/004728750003900104

Andereck, K.L., Valentine, K.M., Knopf, R.C. \& Vogt, C.A., 2005, 'Residents' perceptions of community tourism impacts', Annals of Tourism Research 32(4), 1056-1076. $\mathrm{http}: / / \mathrm{dx}$.doi.org/10.1016/j.annals.2005.03.001

Anthony, B., 2007, 'The dual nature of parks: Attitudes of neighbouring communities to Kruger National Park, South Africa', Environmental Conservation 34(3), 236245. http://dx.doi.org/10.1017/S0376892907004018 
Baral, N. \& Heinen, J.T., 2007, 'Resources use, conservation attitudes, management intervention and park-people relations in the Western Terai landscape of Nepal', Environmental Conservation 34,64-72. http://dx.doi.org/10.1017/ Nepal, Environmental
S0376892907003670

Borrini-Feyerabend, G., Kothari, A. \& Oviedo, G., 2004, Indigenous and local communities and protected areas: Towards equity and enhanced conservation IUCN, Gland, viewed 23 January 2012, from http://plateauperspectives.org/pubs/ Indigineous\%20peoples.pdf

Browne-Nuñez, C. \& Jonker, S.A., 2008, 'Attitudes toward wildlife and conservation across Africa: A review of survey research', Human Dimensions of Wildlife 13 , 47-70. http://dx.doi.org/10.1080/10871200701812936

Bruyere, B.L., Beh, A.W. \& Lelengula, G., 2009, 'Differences in perceptions of communications, tourism benefits, and management issues in a protected area of rural Kenya', Environmental Management 43, 49-59. http://dx.doi.org/10.1007/ s00267-008-9190-7

Chandralal, K.P.L., 2010, 'Impacts of tourism and community attitudes towards tourism: A case study in Sri Lanka', South Asian Journal of Tourism and Heritage $3(2), 41-49$

Chidakel, A., 2011, Conservation attitudes and community-based natural resource management in an understocked game management area of Zambia, FIU electronic theses and dissertations, Paper 450, viewed 10 August 2011, from $\mathrm{http}: / /$ digitalcommons.fiu.edu/etd/450

Currie, J.A., 2001, 'Towards sustainable conservation: Community perceptions of game reserves in the Maputoland Region of South Africa: Comparative case studies of Phinda and Mkhuze Game Reserves', Master of Sustainable Environmental Management thesis, Middlesex University.

De Boer, W.F. \& Baquete, D.S., 1998, 'Natural resource use, crop damage and attitudes of rural people in the vicinity of the Maputo Elephant Reserve, Mozambique', Environmental Conservation 25(3), 208-218. http://dx.doi.org/10.1017/ S0376892998000265

De Witt, L., Van der Merwe, P. \& Saayman, M., 2011, 'An ecotourism model for South African National Parks', Proceedings of the International Conference on Tourism and Management Studies, Algarve, Portugal, 26-29 October, vol. II, viewed 02 February 2012, from http://tmstudies.net/index.php/ectms/article/view/311

Dublin, H.T. \& Hoare, R.E., 2004, 'Searching for solutions: The evolution of an integrated approach to understanding and mitigating human-elephant org/10.1080/10871200490505701

Emerton, L., 1999, 'The nature of benefits and the benefits of nature: Why wildlife conservation has not economically benefitted communities in Africa', Community conservation research in Africa: Principles and comparative practice 9 , Institute for Development Policy and Management, University of Manchester.

Emptaz-Collomb, J-G.J., 2009, 'Linking tourism, human wellbeing and conservation in the Caprivi Strip (Namibia)', PhD thesis, University of Florida, viewed 15 February 2012, from http://etd.fcla.edu/UF/UFE0041031/emptazcollomb j.pd

Gadd, M.E., 2005, 'Conservation outside of parks: Attitudes of local people in Laikipia, Kenya', Environmental Conservation 32(1), 50-63. http://dx.doi.org/10.1017/ S0376892905001918

Gillingham, S. \& Lee, P.C., 1999, 'The impact of wildlife-related benefits on the conservation attitudes of local people around the Selous Game Reserve, Tanzania', Environmental Conservation 26(3), 218-228. http://dx.doi.org/10.1017/ S0376892999000302

Gillingham, S. \& Lee, P.C., 2003, 'People and protected areas: A study of local perceptions of wildlife crop-damage conflict in an area bordering the Selous Game Reserve, Tanzania', Oryx 37(3), 316-325. http://dx.doi.org/10.1017/ S0030605303000577

Groom, R. \& Harris, S., 2008, 'Conservation on community lands: The importance of equitable revenue sharing', Environmental Conservation 35(3), 242-251. http:// dx.doi.org/10.1017/S037689290800489X

Hill, C.M., 2004, 'Farmers' perspectives of conflict at the wildlife-agriculture boundary Some lessons learned from African subsistence farmers', Human Dimensions of Wildlife 9(4), 279-286. http://dx.doi.org/10.1080/10871200490505710

Hoon, P.N., 2004, IImpersonal markets and personal communities? Wildlife conservation and development in Botswana', Journal of International Wildlife Law \& Policy 7(3), 143-160. http://dx.doi.org/10.1080/13880290490883223

Hulme, D. \& Murphree, M. (eds.), 2001, African wildlife and livelihoods: The promise and performance of community conservation, pp. 106-130, James Currey Ltd Woodbridge.

Kideghesho, J.R., Røskaft, E. \& Kaltenborn, B.P., 2007, 'Factors influencing conservation attitudes of local people in Western Serengeti, Tanzania', Biodiversity Conservatio 16, 2213-2230. http://dx.doi.org/10.1007/s10531-006-9132-8

Larson, K., 2010, 'Attitudes concerning conservation in two different wildlife areas in Kenya', Swedish University of Agricultural Services, Department of Anima and Environment and Health Ethology and Animal Welfare programme, Student report 320, viewed 03 May 2013, from http://stud.epsilon.slu.se/1584/

Lepp, A., 2007, 'Resident's attitudes toward tourism in Bigodi village, Uganda', Tourism Management 28, 876-885. http://dx.doi.org/10.1016/j.tourman.2006.03.004

Lepp, A. \& Holland, S., 2006, 'A comparison of attitudes toward state-led conservation and community-based conservation in Bigodi village, Uganda', Society and Natural Resources 19, 609-623. http://dx.doi.org/10.1080/08941920600742377

Makindi, S.M., 2010, 'Communities' perceptions and assessment of biodiversity conservation strategies: The case of protected areas in Kenya', PhD thesis, School of Environmental Sciences, University of Kwazulu-Natal.
Mbaiwa, J.E. \& Stronza, A.L., 2011, 'Changes in resident attitudes towards tourism development and conservation in the Okavango Delta, Botswana', Journal of Environmental Management 92(8), 1950-1959. http://dx.doi.org/10.1016/j. jenvman.2011.03.009, PMid:21482448

McGehee, N.G. \& Andereck, K.L., 2004, 'Factors predicting rural residents' support of tourism', Journal of Travel Research 43, 131-140. http://dx.doi. org/10.1177/0047287504268234

Mehta, J.N. \& Heinen, J.T., 2001, 'Does community-based conservation shape favourable attitudes among locals? An empirical study from Nepal', Environmental Management 28(2), 165-177. http://dx.doi.org/10.1007/s002670010215

Mehta, J.N. \& Kellert, S.R., 1998, 'Local attitudes toward community-based conservation policy and programmes in Nepal: A case study in the Makalu-Barun Conservation Area', Environmental Conservation 25(4), 320-333. http://dx.doi. org/10.1017/S037689299800040X

Musumali, M.M., Larsen, T.S. \& Kaltenborn, B.P., 2007, 'An impasse in community based natural resource management implementation: The case of Zambia and Botswana', Oryx 41(3), 306-313. http://dx.doi.org/10.1017/S0030605307000518

Nepal, S.K., 2002, 'Linking parks and people: Nepal's experience in resolving conflicts in parks and protected areas', International Journal of Sustainable Development and World Ecology 9(1), 75-90. http://dx.doi.org/10.1080/13504500209470104

Newmark, W.D., Manyanza, D.N., Gamassa, D-G.M. \& Sariko, H.I., 1994, 'The conflict between wildlife and local people living adjacent to the protected areas in Tanzania: Human density as a predictor', Conservation Biology 8(1), 249-255. http://dx.doi.org/10.1046/j.1523-1739.1994.08010249.x

Nunkoo, R. \& Ramkissoon, H., 2011, 'Developing a community support model for tourism', Annals of Tourism Research 38(3), 964-988. http://dx.doi.org/10.1016/j. annals.2011.01.017

Rodriguez, S.L., 2008, 'Perceptions and attitudes of a Maasai community regarding wildlife-damage compensation, conservation and the predators that prey on their livestock', Human Dimensions of Wildlife 13(3), 205-206. http://dx.doi. org/10.1080/10871200801886137

Romañach, S.S., Lindsey, P. \& Woodroffe, R., 2007, 'Determinants of attitudes towards predators in central Kenya and suggestions for increasing tolerance in livestock dominated landscapes', Oryx 41(2), 185-195. http://dx.doi.org/10.1017/ S0030605307001779

Sandbrook, C. \& Adams, W.M., 2012, 'Accessing the impenetrable: The nature and distribution of tourism benefits at a Ugandan National Park', Society and Natura Resources 25(9), 915-932. http://dx.doi.org/10.1080/08941920.2011.644394

Sarker, A.H.M.R. \& Røskaft, E., 2010, 'Human attitudes towards conservation of Asian elephants (Elephas maximus) in Bangladesh', International Journal of Biodiversity and Conservation 2(10), 316-327, viewed 02 April 2013, from http://www. academicjournals.org/article/article1380538795_Sarker\%20and\%20Røskaft.pdf

Scanlon, L.J. \& Kull, C.A., 2009, 'Untangling the links between wildlife benefits and community-based conservation at Torra Conservancy, Namibia', Development Southern Africa 26(1), 75-93. http://dx.doi.org/10.1080/03768350802640107

Sekhar, N.U., 2003, 'Local people's attitudes towards conservation and wildlife tourism around Sariska Tiger Reserve, India', Journal of Environmental Management 69, 339-347. http://dx.doi.org/10.1016/j.jenvman.2003.09.002, PMid:14680895

Shibia, M.G., 2010, 'Determinants of attitudes and perceptions on resource use and management of Marsabit National Reserve, Kenya', Journal of Human Ecology 30(1), 55-62

Sifuna, N., 2010, 'Wildlife damage and its impact on public attitudes toward conservation: A comparative study of Kenya and Botswana, with particular reference to Kenya's Laikipia Region and Botswana's Okavango Delta region', Journal of Asian and African Studies 45, 274-296. http://dx.doi. org/10.1177/0021909610364776

Simelane, T.S., Kerley, G.I.H. \& Knight, M.H., 2006, 'Reflections on the relationships between communities and conservation areas of South Africa: The case of five South African national parks', Koedoe 49(2), 85-102. http://dx.doi.org/10.4102/ kouth African nation

Snyman, S., 2012a, 'Ecotourism joint ventures between the private sector and communities: An updated analysis of the Torra Conservancy and Damaraland Camp, Namibia', Tourism Management Perspectives 4, 127-135 http://dx.doi. org/10.1016/j.tmp.2012.07.004

Snyman, S., 2012b, 'The impact of land management systems on community attitudes towards tourism and conservation in six southern African countries', Parks 18(2), 20-31.

Snyman, S., 2012c, 'The role of ecotourism employment in poverty reduction and community perceptions of conservation and tourism in southern Africa', Journa of Sustainable Tourism 20(3), 395-416. http://dx.doi.org/10.1080/09669582.20 12.657202

Snyman, S., 2013, 'High-end ecotourism and rural communities in southern Africa: A socio-economic analysis', PhD dissertation, School of Economics, University of Cape Town.

SPSS version 12, 2004, computer software, IBM Corportation, New York.

STATA version 10.2, 2008, computer software, StataCorp, College station.

Stem, C.J., Lassorie, J.P., Lee, D.R., Deshler, D.D. \& Schelhas, J.W., 2003, 'Community participation in ecotourism benefits: The link to conservation practices and perspectives', Society and Natural Resources 16, 387-413. http://dx.doi. org/10.1080/08941920309177

Stronza, A. \& Gordillo, J., 2008, 'Community views of ecotourism', Annals of Tourism Research 35(2), 448-468. http://dx.doi.org/10.1016/j.annals.2008.01.002

Stronza, A. \& Pêgas, F., 2008, 'Ecotourism and conservation: Two cases from Brazil and Peru', Human Dimensions of Wildlife 13, 263-279. http://dx.doi. org/10.1080/10871200802187097 
Tessema, M.E., Ashenafi, Z.T., Lilieholm, R.J. \& Leader-Williams, N., 2007, 'Community attitudes toward wildlife conservation in Ethiopia', Proceedings of the 2007 George Wright Society Conference, Assessing public attitudes and experiences, St Paul, Minnesota, 16-20 April, viewed 03 May 2013, from http://www.georgewright. org/0755tessema.pdf

Teye, V., Sönmez, S.F. \& Sirakaya, E., 2002, 'Resident attitudes toward tourism development', Annals of Tourism Research 29(3), 668-688. http://dx.doi. org/10.1016/S0160-7383(01)00074-3

Walpole, M.J. \& Goodwin, H.J., 2001, 'Local attitudes towards conservation and tourism around Komodo National Park, Indonesia', Environmental Conservation 28(2), 160-166. http://dx.doi.org/10.1017/S0376892901000169

Walpole, M.J. \& Thouless, C.R., 2005, 'Increasing the value of wildlife through nonconsumptive use? Deconstructing the myths of ecotourism and community-based tourism in the tropics', in R. Woodroffe, S. Thirgood \& A. Rabinowitz (eds.), People and wildlife: Conflict or coexistence?, pp. 122-139, The Zoological Society of London and Cambridge University Press, Cambridge.
Wang, Y. \& Pfister, R.E., 2008, 'Resident's attitudes toward tourism and perceived personal benefits in a rural community', Journal of Travel Research 47(1), 84-93. http://dx.doi.org/10.1177/0047287507312402

Waylen, K.A., McGowan, P.J.K., Pawi Study Group \& Milner-Gulland, E.J., 2009, 'Ecotourism positively affects awareness and attitudes but not conservation behaviours: A case study at Grand Riviere, Trinidad', Oryx 43(3), 343-351. http:// behaviours: A case study at Grand Riviere,
dx.doi.org/10.1017/S0030605309000064

Weladji, R.B., Moe, S.R. \& Vedeld, P., 2003, 'Stakeholder attitudes toward wildlife policy and the Bénoué Wildlife Conservation Area, North Cameroon' Environmental Conservation 30(4), 334-343. http://dx.doi.org/10.1017/S0376892903000353

Woodroffe, R., Thirgood, S. \& Rabinowitz, A., 2005, 'The future of co-existence: Resolving human-wildlife conflicts in a changing world', in R. Woodroffe, S. Thirgood \& A. Rabinowitz (eds.), People and wildlife: Conflict or coexistence? pp. 388-405, The Zoological Society of London and Cambridge University Press, Cambridge. 